\title{
Exploring new approaches
}

\section{to pathways from early childhood education to school}

\section{Sally Peters}

Aotearoa New Zealand's early childhood curriculum Te Whäriki includes the explanation that "A weaver weaves in new strands of harakeke or pandanus as their whāriki expands..." (Ministry of Education, 2017, inside cover). The joining of new material to the whāriki symbolises new learning. This metaphor of a continued weaving offers a particular approach to understanding learning pathways as children transition to school. This article discusses transition in the light of this metaphor and explores the links between Te Whäriki and The New Zealand Curriculum (Ministry of Education, 2007). Drawing on initial work by teachers it reflects on the possibilities of new strategies and practices to enhance the transition experiences of children and families.

$\mathrm{n}$ pathways of lifelong learning there are some key transition points along the way. For young

children there are often transitions to, within, and between early childhood settings and then from early childhood education [ECE] to school. New Zealand's early childhood curriculum Te Whäriki (Ministry of Education, 2017) recognises the importance of these different transitions throughout the document and pays particular attention to the pathways for learners as they move from early childhood education to school and kura.

This article draws attention to the approach to transition in the current New Zealand curriculum documents and discusses some of the possibilities for transition practice offered by Te Whāriki (Ministry of Education, 2017). Examples of teacher practice in which teachers in ECE and school worked together to explore ways to identify and acknowledge children's existing knowledge are discussed. The article reflects on key implications for teachers in ECE and the early levels of school as they review their practice in light of the updated Te Whäriki curriculum.

\section{Learning pathways in Te Whāriki}

Te Wharriki includes an explanation that the weaving image on the cover represents the underside of the whäriki and that while the "upper side [of a whäriki] reveals the artistry... Expert weavers will examine the foundations for planning and technique. If these are sound, the quality will be seen on the face-up side" (Ministry of Education, 2017, inside cover). This attention to the process and quality of the weaving of the curriculum also includes an understanding of the weaving in of new strands, representing new learning. Māori and English versions of Te Whäriki (Ministry of Education, 2017) are in one document, brought together as a flip book, with the two different versions meeting in the middle. When the curriculum is opened at the place where the two parts of the book meet, "it can be seen that the whäriki is unfinished, with loose strands still to be woven. This acknowledges the child's potential and their ongoing educational journey" (Ministry of Education, 2017, inside cover).

The whāriki image symbolises the start of a journey that will "take the traveller beyond the horizon" on a learning journey that begins before birth and continues throughout life (Ministry of Education, 2017, p.11). The underpinning concept of the whāriki enables and supports diversity. As the pathway continues when children move from ECE to school it is recognised that ideally newentrant teachers (and, where involved, specialist support services) join with early childhood kaiako, parents, 


\section{The whāriki image}

\section{symbolises the}

\section{start of a journey}

\section{that will "take the}

\author{
traveller beyond
}

\section{the horizon" on a}

learning journey

\section{that begins before}

\section{birth and continues}

\author{
throughout life.
}

\section{The underpinning}

and whānau, and work together to support children's learning continuity as they make this transition. There are shared expectations across early childhood and school settings:

Each part of the education system has a responsibility for supporting children (and the adults they become) on this lifelong journey of exploration. Kaiako and new entrants teachers support children by affirming their identity and culture, connecting with and building on their funds of knowledge and having positive expectations for their learning. (Ministry of Education, 2017, p. 51)

The New Zealand Curriculum (Ministry of Education, 2007) (NZC) also places responsibility on schools to support children's transition to school. One of the principles of $N Z C$ is coherence; the curriculum "provides for coherent transitions and opens up pathways to future learning" (NZC, p. 9). Connecting each stage of the journey is explained in more detail under a Learning Pathways section, which notes that "schools can design their curriculum so that students find the transitions positive and have a clear sense of continuity and direction" (NZC, p. 41). A shared approach across ECE and school is supported by the similar visions for learners across Te Whäriki (Ministry of Education, 2017), NZC, and Te Marautanga o Aotearoa, the parallel curriculum for Māorimedium schooling (Ministry of Education, 2008).

In Te Whäriki (Ministry of Education, 2017) the practicalities of continuing the learning pathway at school is introduced in a table that provides a comprehensive indication of places to start for ECE and school teachers in making connections between the strands of Te Whäriki and the school curriculum. These links are a starting point for teachers' own explorations, and each section (Ministry of Education, 2017, pp. 53-57) recognises that:

local curriculum design involves a complex weaving of principles and strands (Te Whäriki), values, key competencies and learning areas (The New Zealand Curriculum) ... [and] values and learning areas (Te Marautanga o Aotearoa) as children and young people engage in learning experiences.

Acknowledging this complex weaving and the breadth of possible connections expands on $N Z C$ s alignment between Te Whäriki's strands and the key competencies at school. The 2017 approach provides a greater recognition that the realms of mana represented in the five strands of Te Whāriki are a basis for learning, and are relevant across the lifespan and relate not just to the key competencies, but to all aspects of learning.

\section{Split-screen pedagogy}

Another connection between the approaches to learning in ECE and school that is reflected in the 2017 Te Wharriki is the need for a "split-screen" pedagogy that "maintains a dual focus on the 'how' and the 'what' of learning" (Ministry of Education, 2017, p. 52). This was promoted in terms of $N Z C$, where Chamberlain (2008) explained split-screen thinking was about doing two things at once-teaching concepts and strengthening learning capacity at the same time.

Claxton, Chambers, Powell and Lucas (2011) describe how children experience the values and practices that signal what is valued in learning whether or not teachers pay attention to this. Therefore, what teachers do and say, what they notice and commend, all influence the ways in which key competencies or learning dispositions are influenced. A split-screen pedagogy deliberately attends to working theories and learning dispositions, or learning areas and key competencies. It gives attention to the knowledge skills and attitudes we want young people to have for life. Not only what they learn, also the kinds of learners that they are (Claxton, et al., 2011).

In ECE, split-screen pedagogy has also been called a "dual focus pedagogy" and in some cases dispositions have been prioritised over working theories (Carr, Cowie \& Davies, 2015; Mitchell, et al., 2015). The split-screen approach highlights that both are important.

\section{Understanding transitions}

As teachers work with the approach to learning pathways outlined in Te Whäriki (Ministry of Education, 2017) it is useful to reflect on some of the research findings that can assist. When reviewing international literature it is relevant to note the range of ages at which children start school. While in New Zealand children generally start school on or near their 5th birthday, Sharp (2002) outlined that over half of European countries have school entry at age 6, and in three Scandinavian countries and five Eastern European countries children start school at age 7. More recent UNESCO 
(2017) figures show that less than $15 \%$ of countries have children starting school before age 6 , figures also reflected in the World Bank (2016) data on official entrance ages to primary education.

Whatever age children start school, this transition can be a time both of vulnerability and of opportunity. Bronfenbrenner's ecological model draws attention to the patterns of activities, roles, and relationships experienced in a given setting (microsystem) and the ways in which a child's positioning in the ecological environment is altered during a transition, as a result of entry into a new microsystem (Bronfenbrenner, 1979). Drawing on the anthropological work of van Gennep (1977), the transition can be seen as being on a threshold between two worlds, described as a liminal phase or limen. He described transitions that involved rites of separation (from the old), rites of transition, and rites of incorporation (into the new). Bridges (1986) used these phases to explain why a transition is different from a change. He argues a change simply means stopping one thing and starting another, or doing something in a different way. It is the effects of that change on people that lead to consideration of transitions, the three phases of which may take longer than the change itself. Transitions pay attention to the experiences of the person as they leave behind familiar roles and relationships, experience a transitional or liminal phase, and (hopefully) reincorporate into the new relationships and new competencies. The threshold between what was and what is to come can be disorienting and confusing, but also a time of possibilities (Ackesjö, 2014).

The length of a transition might vary for different children, potentially beginning as they are aware of the move to school approaching and continuing after they are physically located in the new context of school, as it may take some time until they are incorporated into the new role and have formed new relationships. Until this incorporation is achieved, they can be thought of as still on a threshold in the liminal phase. Case studies of children from 4 years old until they were in the second year of school illustrated the complex interaction of factors that can affect how this transition is experienced (Peters, 2004). External factors at other levels of the environment (meso-, exo- and macrosystems) also contribute to each individual's cycle of experience as does the proximal processes; the enduring and "progressively more complex reciprocal interaction" between an individual and "the persons, objects and symbols" in the environment, over time (Bronfenbrenner \& Ceci, 1994, p. 572). As children's learning pathways navigate this threshold between ECE and school microsystems, whilst weaving on the new learning as proposed in Te Whäriki (Ministry of Education, 2017), attention to supporting other aspects of the transition may enhance the opportunities the move affords.

\section{Supporting transitions}

There has been breadth of research on supporting transition to school both nationally and internationally, which can only be touched on here. One key theme in this literature which relates to the curricula in ECE and school in New Zealand is the notion of "belonging" [Belonging/Mana whenua in Te Whäriki (Ministry of Education, 2017), and within the key competency participating and contributing in $N Z C$ ]. For example, an extensive review of research literature commissioned by the Ministry of Education highlighted belonging, wellbeing, and feeling "suitable" at school as one of factors which could support transitions (Peters, 2010). A similar theme was identified in a report by the Education Review Office [ERO] (2015), which noted the importance of schools' practices that helped children and their families develop a sense of belonging. This links to Hohepa and Paki's (2017) consideration of türangawaewae, which is an important concept for Māori. "Its literal meaning is 'a standing place for feet'. It symbolises a place with a sense of belonging, empowerment and connection" (p. 104). They found this was relevant for transitions.

The literature reviewed by Peters (2010) also identified recognition and acknowledgement of culture as important for successful transitions. "Cultural values provide and support culturally responsive transitions ... As children transition to school as 'individuals' they also represent knowledge frameworks, values and beliefs belonging to their culture" (Hohepa \& Paki, 2017, p. 108). ERO (2015) highlighted that culturally responsive teaching and assessment contributed to children's sense of themselves as confident learners.

Other aspects that the review by Peters (2010) found are relevant to consider in supporting transitions include:

- engagement in learning

- identity as a learner
- positive teacher expectations

- building on funds of knowledge from early childhood education and home

- respectful, reciprocal relationships (Peters, 2010).

In addition, ERO (2015) noted the role ECE and school leaders play when they place "emphasis on the importance of transition to ensure continuity of learning for children" (p. 1). Similarly, our research (Peters, Paki, \& Davis, 2015) identified the key role of supportive management and policies for teachers working to enhance transition practices.

\section{Learning journeys from early childhood into school}

This section shares some of the findings from research with ECE and school teachers who worked together to understand and explore children's learning journeys from ECE to school. (For the full report see Peters et al., 2015.) We sought to provide insights into what successful transitions might look like from the perspectives of those involved, and how they might be achieved. We were also interested in how transition experiences might affect learning.

Although the research was conducted before the refreshing of Te Whariki (Ministry of Education, 2017), examples below help illustrate how teachers in ECE and the early levels of school might begin to explore pathway connections between Te Whäriki and NZC (see the table in Ministry of Education, 2017, pp. 53-57). The schools in our research are English medium, but the same table can be used to start exploring connections with $T e$ Marautanga o Aotearoa (Ministry of Education, 2008).

The project was based in two schools and three early childhood centres in the North Island of New Zealand. Throughout the project there was a core team of at least 12 teacher researchers and strong support from the two school principals. A range of data were gathered. This article looks at interview and observation data related to small action research miniprojects undertaken by the teachers, each with the aim of enhancing an aspect of the transition journeys. The interviews reported on here were conducted by the university researchers with the teachers. Narrative observations were undertaken by the teacher-researchers (with teacher release to do so). Research field notes were also gathered by teachers during normal practice. 
As a useful background to developing the mini action-research projects designed to enhance transitions, teachers spent time observing in the "other" setting and then discussing what they had seen with the teachers(s) they had watched to gain an understanding of the learning and teaching which they had observed. The intention was to understand what was happening from the other person's point of view rather than judging from one's own knowledge base. One example was an activity that involved new-entrant children cutting out shapes and gluing them to make a picture. When discussing this with the school teacher, the ECE teacher noted "It is really interesting because in our training you wouldn't use templates". The school teacher explained that for her this activity was about coordination in using the scissors, and in selfmanaging a task:

It's even things like organisation and self-management. It's like, I've got a lot of pieces here I have to manage these pieces so I am not losing them. And then I have to think about how I am going to lay it on the paper. I have to learn that I lay it first and then stick it, or else I'll get these disasters. And they have got a lot better at that.

Managing self is a key competency in NZC that can be woven on from the Wellbeing / Mana atua strand of Te Whäriki, which includes children managing themselves and expressing their feelings and needs. The ECE teacher, initially uncomfortable with the activity, later reflected "it's part of the competencybased learning too, it's the skill element. It is refining those skills so that they can then apply it in a different way". Coming to a shared understanding of the intended learning opened space to reflect that making links is not about using templates in ECE, but in finding ways to consider how competencies such as managing self in each setting are evident and could be connected, even though the nature of the tasks and opportunities might be different.

School teachers from this school, observing in the ECE centre, commented on the engagement and attention span they noticed when the children were pursuing their own interests within the free-play environment and the competence with equipment such as glue guns. This opened new thinking and discussion about how managing self, which includes "They are enterprising, reliable and resilient, set personal goals and have strategies for meeting challenges" (NZC, p. 12) might look in their school context.

In the second school, a teacher discussed how:

they [children] need to share their profile books when they come up the road. I think that is so important because that tells us and the children in the classroom who they are, what they loved doing at early childhood, and it shows all the people that were there, and often that's some of the children that are here. So that's a really huge gift that they can bring with them.

Building on that knowledge from the profiles or portfolios from ECE-in some cases specific collaborations-helped to see how the weaving on might happen. One of the ECE teachers used the visual of a wharenui to conceptualise the notion of transition from a Māori perspective:

A successful transition can be likened to a wharenui. The foundations that hold the wharenui to me represent the tamariki, whānau, teachers, and our community ... if we connect as one, support and manaki each other then we grow together as a whānau that makes that strong foundation. When this happens the structure of the wharenui is strong and united and our learning is enriched and meaningful. Umm you know what it is ... it's about whanaungatanga and kotahitanga ... if we get that right ... ka ora ai te katoa.

Teachers from ECE settings and school in this community spoke about the importance of working together to support and manaki one another, and through their connections, to learn if children have any particular interests related to familiar resources. For example, a school teacher spoke about how a Māori boy transitioning from the Māori-medium ECE setting to this English-medium school appeared to her to settle in better and be more engaged when he found a book he was familiar with from ECE. The school teacher believed that the connection he had to a familiar object allowed him to settle and feel he belonged in his new environment. The Māori-medium ECE teachers offered to undertake a cultural audit of the school's resources and make some recommendations so that the school could have available more familiar and enjoyed resources that connected to the children's interests.

In this case the NZC key competency participating and contributing, which includes "they have a sense of belonging and the confidence to participate in new contexts" (NZC, p. 13), can continue the weaving from the strand of Belonging / Mana whenua in ECE. Both relate to tūrangawaewae, which, as noted earlier, Hohepa and Paki (2017) described as "a place with a sense of belonging, empowerment and connection” (p.104). It also linked children's interests in ECE to learning areas at school. In the book example given, the Communication / Mana reo strand potentially continues with both the NZC key competency of using language, symbols and texts and the learning area of English where "Students study, use and enjoy language and literature" (NZC, p. 17).

In the other school community, a letterwriting activity began when children from one ECE setting began sending letters and pictures to children from the centre that were now at school. The school principal delivered the letters, joining first with the ECE children to collect them and then with the new-entrant children to deliver. They were so well-received that the teachers decided to instigate a letterwriting activity which meant that all the children in the new-entrant class at school could correspond with children at the ECE centre, whether they had attended that centre themselves. Through visits the children got to know one another and they all had a buddy to write to (which could include drawing, writing, or other forms of "letter"). This built relationships for ECE children before they got to school, creating some familiarity with others in the new-entrant class. It let new-entrant teachers see the interests and abilities of the ECE children as they shared their drawings and letters. Information about the approach to emergent literacy taken in the school was shared and discussed with the ECE teachers. The principal's delivery role was also an important connection, letting children and families get to know him in the ECE context.

This activity connected both the building of relationships in ECE Contribution/ Mana tangata to the NZC key competency relating to others. It also provided a specific connection between Communication / Mana reo "Recognising print symbols and concepts and using them with enjoyment, meaning and purpose" (Ministry of Education, 2017, p. 25) with the $N Z C$ key competency using language, 
symbols and texts: "They learn that languages and symbols are systems for representing and communicating information, experiences and ideas" (NZC, p. 12) and the learning area of English where "students study, use and enjoy language and literature communicated orally, visually or in writing" (NZC, p. 17).

\section{Discussion}

The examples described above show some possible starting points for making connections between Te Wharriki (Ministry of Education, 2017) and NZC (p. 17). Although only showing surface connections, they illustrate a place to begin exploring the curriculum in the other sector to deepen understanding. The pathways section of Te Whariki provides the opportunity to undertake a more detailed and nuanced approach that looks closely at the child's learning journey and how the learning in ECE can continue into school. As teachers gain familiarity with one another's documents the links can be more complex.

Ideally, children's learning over time will be documented showing split-screen or dual focus (Carr et al., 2015; Claxton et al., 2011; Mitchell et al., 2015) attention to learning dispositions and working theories associated with the strands of Te Whariki so that there will be a balanced weaving in ECE. Loose strands of the unfinished weaving can be taken up in the weaving in of the values, key competencies and learning areas of $N Z C$. What the curricula look like in action is a rich site for discussion as the example above showed, where teachers discussed how managing self might look in ECE and school contexts. This led to a deeper appreciation of the concept itself.

Transitions can be a time of uncertainty as children navigate entry into a new microsystem (Bronfenbrenner, 1979), potentially experiencing a number of challenges as they disengage from the familiar and are incorporated into the new (van Gennep, 1977). If we pay attention to the development of mana across the sectors each child will be respected and nurtured; their "physical, mental, spiritual, and emotional strength will build mana, influence and control ... having mana is the empowering tool to controlling their own destiny" (Reedy, 2013, p. 47). Although, as described above, sharing children's profile books and ensuring familiar resources helped to establish a sense of belonging for children in our study, it would be exciting to explore a more deliberate focus on seeing how fostering the realms of mana from the strands of $T e$ Whäriki both in ECE and at school could guide transition practices and provide a focus for all learners.

Meaningful shared activities such as the letter-writing example demonstrate the splitscreen pedagogy in action, in this case building relationships through art and literacy. It also shows that the same activity can be appropriate in both ECE and school and be meaningfully documented against the learning outcomes of both the ECE and school curricula. The possibilities for learning at school to be fostered through play-based activities has also been illustrated in studies such as Davis (2015). With New Zealand children being some of the youngest internationally when they start school this is an important consideration to explore further.

ERO (2015) found practice was variable in how well early childhood centres were implementing the curriculum and in how well children were supported as they approached the transition to school. Similarly, there was variability in how responsive schools were to new children (and families). Examples of practice and evaluation frameworks were included in the report so ECE settings and schools can self-review their approaches to transition (ERO, 2015). Hopefully Te Whāriki (Ministry of Education, 2017) will stimulate increased interest in high quality curriculum implementation and evaluating approaches to transition in both sectors.

\section{Conclusion}

Te Whäriki Online (Ministry of Education, n.d.) is a resource that explores some of the key ideas underpinning the curriculum. One of these, Pathways and Transitions provides valuable information for understanding, planning for, and reflecting on transitions. It makes links to the principles of Te Whäriki in relation to transitions and shares some stories of practice. This article adds to the Te Whäriki Online resource by illustrating how teachers might begin to implement the approach to weaving on new strands of learning to the whäriki as children's pathways cross the threshold between ECE and school. This approach acknowledges Te Wharriki and its focus on mana in each strand as a base for ongoing approaches to learning.

The nature of the data gathered for our learning-journey projects have provided a starting point in thinking about connecting learning in ECE and school. However, with

\section{Transitions can}

\section{be a time of}

\section{uncertainty as}

\section{children navigate}

\section{entry into a new}

microsystem,

potentially

experiencing

a number of

challenges as they

disengage from

\section{the familiar and}

are incorporated

\section{into the new. If we}

pay attention to

\section{the development of}

mana across the

sectors each child

will be respected

and nurtured... 
the data being gathered prior to the 2017 curriculum the possibilities offered by $T e$ Whāriki (Ministry of Education, 2017) have yet to be fully explored. It would be interesting to investigate how this might look for students making the transition to school now.

\section{Acknowledgements}

I acknowledge with thanks funding from the Teaching and Learning Research Initiative [TLRI] for the project I have drawn on in this article. I am also very grateful to my research partners (Vanessa Paki and Keryn Davis), our teacher-researcher colleagues, and to the children and families who participated in the studies.

\section{References}

Ackesjö, H. (2014). Children's transitions to school in a changing educational landscape: Borders, identities and (dis)continuities. International Journal of Transitions in Childhood, 7, 3-5.

Bridges, W. (1986). Managing organizational transitions, Organisational Dynamics, 15(1), 24-33. https://doi.org/10.1016/00902616(86)90023-9

Bronfenbrenner, U. (1979). The ecology of buman development. Cambridge, MA: Harvard University Press.

Bronfenbrenner, U., \& Ceci, S. J. (1994). Naturenurture reconceptualized in developmental perspective: A bioecological model. Psychological Review, 101(4), 568-586. https://doi. org/10.1037/0033-295X.101.4.568

Carr, M., Cowie, B., \& Davies, K. (2015). Continuity of early learning: Learning progress and outcomes in the early years. [Report on the Literature Scan]. Wellington: Ministry of Education.

Chamberlain, M. (2008, February). Learning's the thing. Presentation at the Learning@School Conference, Rotorua.

Claxton, G., Chambers, M., Powell G., \& Lucas, B. (2011). The learning powered school: Pioneering 21st century education. Bristol: TLO.

Davis, K. (2015). New-entrant classrooms in the re-making. Christchurch: Core Education.

Education Review Office. (2015). Continuity of learning: Transitions from early childhood services to schools. Retrieved from http://www.ero.govt. nz/National-Reports/Continuity-of-learningtransitions-from-early-childhood-services-toschools-May-2015
Hohepa, M., \& Paki, V. (2017). Māori medium education and transition to school. In N. Ballam, B. Perry, \& A. Garpelin (Eds.), Pedagogies of educational transitions (pp. 95-111). Switzerland: Springer Nature. https://doi. org/10.1007/978-3-319-43118-5_7

Ministry of Education. (n.d.). Te Whäriki online. Retrieved from https://tewhariki.tki.org.nz/

Ministry of Education. (1996). Te whäriki: He whāriki mātauranga mō ngà mokopuna o Aotearoa-Early childhood curriculum. Wellington: Learning Media.

Ministry of Education. (2007). The New Zealand curriculum. Wellington: Learning Media.

Ministry of Education. (2008). Te marautanga o Aotearoa. Wellington: Learning Media.

Ministry of Education. (2017). Te whäriki: He whāriki mātauranga mō ngà mokopuna o Aotearoa-Early childhood curriculum. Wellington: Ministry of Education.

Mitchell, L., Cowie, B., Clarkin-Phillips, J., Davis, K., Glasgow, A., Hatherly, A., Rameka, L., et al. (2015). Continuity of early learning: Learning progress and outcomes in the early years. Overview report on data findings. Wellington, New Zealand: Ministry of Education.

Peters, S. (2004). Crossing the border: An interpretive study of children making the transition to school. Unpublished doctoral thesis, University of Waikato.
Peters, S. (2010). Literature review: Transition from early childhood education to school. Wellington: Ministry of Education. Retrieved from http:// www.educationcounts.govt.nz/publications/ ECE/98894/Executive_Summary

Peters, S., Paki, V. \& Davis, K. (2015). Learning journeys from early childhood into school. Teaching and Learning Research Initiative final report. Retrieved from http://www.tlri.org.nz/sites/ default/files/projects/TLRI_\%20Peters_ Summary\%28v2\%29\%20\%281\%29.pdf

Reedy, T. (2013). Toku rangatiratanga nā te manamātauranga: "Knowledge and power set me free ...”. In J. Nuttall (Ed.), Weaving Te Whäriki (pp. 35-53). Wellington: NZCER.

Sharp, C. (2002, November). School starting age. Paper presented at the Local Government Association Seminar, London. http://citeseerx. ist.psu.edu/viewdoc/download?doi=10.1.1.521 $.9674 \&$ rep=rep $1 \&$ type $=$ pdf

UNESCO (2017). Official entrance age to each ISCED level of education. Retrieved from http:// data.uis.unesco.org/index. aspx?queryid $=218$

Van Gennep, A. (1977). The rites of passage. London: Routledge.

World Bank (2016). Official entrance age to primary education (years). Retrieved from https://data.worldbank.org/indicator/SE.PRM. AGES
Sally Peters is an associate professor at the Faculty of Education, University of Waikato. Sally has a background in early childhood education and a particular interest in children's development from o to 8 years. Sally has led or co-led a number of research projects exploring aspects of transition experiences, most recently leading the New Zealand team in a Marie Curie International Research Staff Exchange Scheme (IRSES) project focused on Pedagogies of Educational Transitions (POET). Many of her projects have involved working in partnership with teachers. She was part of the writing team for the update of the New Zealand early childhood curriculum, Te Whäriki.

Email: spetersळwaikato.ac.nz 